\title{
Nomenclature and listing of celiac disease relevant gluten T-cell epitopes restricted by HLA-DQ molecules
}

\author{
Ludvig M. Sollid • Shuo-Wang Qiao • \\ Robert P. Anderson • Carmen Gianfrani • Frits Koning
}

Received: 9 November 2011 / Accepted: 13 January 2012/Published online: 10 February 2012

(C) The Author(s) 2012. This article is published with open access at Springerlink.com

\begin{abstract}
Celiac disease is caused by an abnormal intestinal T-cell response to gluten proteins of wheat, barley and rye. Over the last few years, a number of gluten T-cell epitopes restricted by celiac disease associated HLA-DQ molecules have been characterized. In this work, we give an overview of these epitopes and suggest a comprehensive, new nomenclature.
\end{abstract}

Keywords Celiac disease $\cdot$ Gluten $\cdot$ T cell $\cdot$ Epitopes $\cdot$ HLA-DQ2 · HLA-DQ8

Celiac disease (CD) is caused by an abnormal intestinal immune response to proline and glutamine-rich wheat gluten proteins and to similar proteins in barley and rye (Green and Cellier 2007). Oat is generally considered safe for consumption by CD patients (Garsed and Scott 2007), although some patients appear to be sensitive to oat as well

L. M. Sollid $(\bowtie) \cdot$ S.-W. Qiao

Centre for Immune Regulation and Department of Immunology, University of Oslo and Oslo University Hospital - Rikshospitalet, Oslo, Norway

e-mail: 1.m.sollid@medisin.uio.no

R. P. Anderson

Walter and Eliza Hall Institute of Medical Research, Parkville,

Victoria, Australia

C. Gianfrani

Institute of Food Science, National Research Council,

Avellino, Italy

F. Koning

Department of Immunohematology and Blood Transfusion,

Leiden University Medical Center,

Leiden, The Netherlands
(Lundin et al. 2003). The only established treatment for the disease is a lifelong gluten exclusion diet.

$\mathrm{CD}$ has a strong HLA association. The most prominent association is with HLA-DQ2.5 (DQA 1*05:01, DQB1*02:01) (Table 1). In individuals who carry the DR3DQ2 haplotype, this molecule is encoded by DQA1 and DQB1 alleles located on the same chromosome (in cis configuration), whereas in individuals who are DR5DQ7/DR7DQ2 heterozygous it is encoded by alleles located on opposite chromosomes (trans configuration) (Sollid et al. 1989). Most of the remaining patients carry DR4DQ8 haplotypes, and in these patients it is the DQ8 molecule encoded by DQA $1 * 03$, DQB1*03:02 that is involved in the pathogenesis (Lundin et al. 1994). In the small remaining population of CD patients that are neither DQ2.5 or DQ8, the patients typically express HLA-DQ molecules that contain 'half' of DQ2.5 molecule as they are either DQ2.2 (DQA1*02:01, DQB1*02:01) or DQ7.5 (DQA1*05, DQB1*03:01) (Karell et al. 2003). As both the DQA1 and DQB1 loci are polymorphic, unique HLA-DQ molecules can be encoded in trans configuration. Examples of such molecules are DQ2.3 (DQA1*03, DQB1*02:01) and DQ8.5 (DQA1*05, DQB1*03:02) found in DR3DQ2/ DR4DQ8 heterozygous individuals (Table 1).

$\mathrm{CD}^{+} \mathrm{T}$ cells of CD patients (Lundin et al. 1993), but not healthy subjects (Molberg et al. 1997), recognize gluten peptides when presented by disease associated HLA-DQ molecules. This was first shown for DQ2.5 and DQ8 (Lundin et al. 1994), and recently it was demonstrated that DQ2.2 patients (Bodd et al. 2012) and a patient who carries DQ8.5 in a rare cis configuration (Kooy-Winkelaar et al. 2011) also have glutenreactive $\mathrm{T}$ cells in the intestinal mucosa. Gluten-reactive $\mathrm{T}$ cells can readily be established from intestinal biopsies cultured in vitro (Camarca et al. 2009; Lundin et al. 1993, 1994; Tye-Din et al. 2010; Vader et al. 2002b; van de Wal et al. 1998b). T cells recognizing the same gluten epitopes are 
Table 1 Description and naming of HLA-DQ molecules that are associated with celiac disease and which are used as antigen presenting elements for $\mathrm{CD}^{+} \mathrm{T}$ cells of celiac disease patients

${ }^{\text {a }}$ Risk for celiac disease has not been established in population studies

${ }^{\mathrm{b}}$ Molecule can also be encoded in cis on some rare haplotypes

\begin{tabular}{|c|c|c|c|c|c|}
\hline \multirow[b]{2}{*}{ HLA-DQ molecule } & \multicolumn{2}{|c|}{ Encoded by } & \multirow{2}{*}{$\begin{array}{l}\text { Risk for celiac } \\
\text { disease }\end{array}$} & \multirow{2}{*}{$\begin{array}{l}\text { Expression in cis } \\
\text { or trans position }\end{array}$} & \multirow{2}{*}{$\begin{array}{l}\text { Part of common } \\
\text { cis haplotype }\end{array}$} \\
\hline & DQA1* & DQB1* & & & \\
\hline HLA-DQ2.5 & 05 & 02 & High & cis, trans & DR3DQ2 \\
\hline HLA-DQ2.2 & 02 & 02 & Low & cis, (trans) & DR7DQ2 \\
\hline HLA-DQ2.3 & 03 & 02 & Likely low ${ }^{\mathrm{a}}$ & trans, $(\text { cis })^{\mathrm{b}}$ & \\
\hline HLA-DQ7.5 & 05 & 03:01 & Very low & cis, (trans) & DR5DQ7 \\
\hline HLA-DQ8 & 03 & 03:02 & Low & cis & DR4DQ8 \\
\hline HLA-DQ8.5 & 05 & 03:02 & Likely low ${ }^{\mathrm{a}}$ & trans, $(\text { cis })^{\mathrm{b}}$ & \\
\hline
\end{tabular}

normally not detected in the peripheral blood (Anderson et al. 2000 ), but can be found in the blood of treated CD patients on day 6 after a 3-day oral gluten challenge (Anderson et al. 2000, 2005; Ráki et al. 2007).

HLA is the most important genetic factor in CD, and carriage of certain HLA alleles is a necessary, but not sufficient, factor for disease development (Sollid 2002). The other factors required for disease development are non-HLA genes, of which 39 loci have been identified so far (Trynka et al. 2011), and possibly environmental factors other than gluten. To note, mice transgenic for HLA-DQ2.5 and gluten specific T-cell receptors do not develop a CD-like enteropathy (de Kauwe et al. 2009; Du Pre et al. 2011). The reason why these mice do not develop enteropathy may relate to fundamental differences in the gut physiology between mouse and man, and to the lack of appropriate non-MHC genes in the mouse strains tested that parallel the non-HLA susceptibility genes of CD patients.

The differential risk of DQ2.5 and DQ2.2 is linked with the T-cell response to gluten. It has been demonstrated that DQ2.5 binds a larger gluten peptide repertoire compared to DQ2.2 (Vader et al. 2003b). Further, gluten T-cell epitopes form stable complexes with DQ2.5, and the increased risk of DQ2.5 over DQ2.2 correlates with a different ability of the two HLA molecules to form stable complexes with many gluten peptides (Fallang et al. 2009).

Characteristically, gluten-reactive $\mathrm{T}$ cells of $\mathrm{CD}$ patients recognize their antigenic peptides much better when specific glutamine residues are converted to glutamate by the enzyme transglutaminase 2 (TG2) (Molberg et al. 1998; van de Wal et al. 1998a). Deamidated gluten peptides bind with increased affinity to DQ2.5 and DQ8 (Arentz-Hansen et al. 2000; Camarca et al. 2009; Henderson et al. 2007; Kim et al. 2004; Moustakas et al. 2000; Quarsten et al. 1999), and the rate of dissociation of deamidated gluten peptides from DQ2.5 has been shown to be substantially slower than for their native counterparts (Xia et al. 2005). The ability to form stable peptide-MHC complexes again seems to be a key factor for the initiation of the anti-gluten T-cell response.
Gluten is defined as the cohesive mass that remains when dough is washed to remove starch (Shewry et al. 1992). Traditionally and strictly speaking, gluten is a name of wheat proteins only, but gluten is now increasingly used as a term to denote proline- and glutaminerich proteins of wheat, barley, rye and oat. In wheat, gluten consists of the gliadin and glutenin subcomponents. The gliadin proteins can be subdivided into $\alpha$-, $\gamma$ - and $\omega$-gliadins, while the glutenin proteins can be subdivided into high molecular weight (HMW) and low molecular weight (LMW) subunits. Common bread wheat is a hexaploid species, and in addition some of the gluten protein encoding genes originate from duplicated loci. Thus, in a single wheat variety there exits up to several hundred different gluten proteins, many of which only differ by a few amino acids. The proline- and glutamine-rich proteins of barley, rye and oat are termed hordeins, secalins and avenins, respectively.

Given the heterogeneity of the wheat gluten proteins, it is no surprise that many distinct gliadin and glutenin derived T-cell epitopes exist (Table 2). T-cell epitopes derived from either $\alpha-, \gamma$-, and $\omega$-gliadins as well as from HMW and LMW glutenins have been reported (Arentz-Hansen et al. 2000; Sjöström et al. 1998; Vader et al. 2002b; van de Wal et al. 1998b). T-cell epitopes in both hordeins and secalins have been described and they are highly homologous to those found in wheat (Tye-Din et al. 2010; Vader et al. 2003a). The avenins of oat are more distinct, and although oat is considered safe for CD patients (Garsed and Scott 2007), some CD patients are clinically sensitive to oat (Lundin et al. 2003). Avenin specific as well as cross-reactive responses have been described (Arentz-Hansen et al. 2004; Vader et al. 2003a).

There is at present no standard nomenclature for CDrelevant gluten epitopes. Here, we propose such a nomenclature based on the following three criteria:

1. Reactivity against the epitope must have been defined by at least one specific T-cell clone. 
Table 2 List of celiac disease relevant T-cell epitopes recognized by $\mathrm{CD}^{+}{ }^{+} \mathrm{T}$ cells

\begin{tabular}{|c|c|c|c|c|c|c|c|c|c|c|c|}
\hline \multirow[t]{2}{*}{ Epitope $^{\mathrm{a}}$} & \multirow[t]{2}{*}{ Previous names } & \multicolumn{9}{|c|}{ Peptide-binding register $^{\mathrm{b}}$} & \multirow[t]{2}{*}{ Reference } \\
\hline & & 1 & 2 & 3 & 4 & 5 & 6 & 7 & 8 & 9 & \\
\hline \multicolumn{12}{|c|}{ DQ2.5 restricted epitopes } \\
\hline DQ2.5-glia- $\alpha 1 \mathrm{a}$ & DQ2- $\alpha-\mathrm{I}, \alpha 9$ & $\mathrm{P}$ & $\mathrm{F}$ & $\mathrm{P}$ & Q & $\mathrm{P}$ & $\mathbf{E}$ & $\mathrm{L}$ & $\mathrm{P}$ & $\mathrm{Y}$ & (Arentz-Hansen et al. 2000) \\
\hline DQ2.5-glia- $\alpha 1 b$ & DQ2- $\alpha-\mathrm{III}$ & $\mathrm{P}$ & $\mathrm{Y}$ & $\mathrm{P}$ & Q & $\mathrm{P}$ & $\mathbf{E}$ & $\mathrm{L}$ & $\mathrm{P}$ & $\mathrm{Y}$ & (Arentz-Hansen et al. 2002) \\
\hline DQ2.5-glia- $\alpha 2$ & DQ2- $\alpha$-II, $\alpha 2$ & $\mathrm{P}$ & $\mathrm{Q}$ & $\mathrm{P}$ & $\mathbf{E}$ & $\mathrm{L}$ & $\mathrm{P}$ & $\mathrm{Y}$ & $\mathrm{P}$ & Q & (Arentz-Hansen et al. 2000) \\
\hline DQ2.5-glia- $\alpha 3$ & glia- $\alpha 20$ & $\mathrm{~F}$ & $\mathrm{R}$ & $\mathrm{P}$ & $\mathbf{E}$ & Q & $\mathrm{P}$ & $\mathrm{Y}$ & $\mathrm{P}$ & Q & (Vader et al. 2002b) \\
\hline DQ2.5-glia- $\gamma 1$ & DQ2- $\gamma-\mathrm{I}$ & $\mathrm{P}$ & Q & Q & $\mathrm{S}$ & $\mathrm{F}$ & $\mathrm{P}$ & $\mathbf{E}$ & Q & $\underline{Q}$ & (Sjöström et al. 1998) \\
\hline DQ2.5-glia- $\gamma 2$ & DQ2- $\gamma$-II, $\gamma 30$ & I & Q & $\mathrm{P}$ & $\mathbf{E}$ & Q & $\mathrm{P}$ & A & Q & $\mathrm{L}$ & (Qiao et al. 2005; Vader et al. 2002b) \\
\hline DQ2.5-glia- $\gamma 3$ & DQ2- $\gamma-\mathrm{III}$ & $\underline{Q}$ & Q & $\mathrm{P}$ & $\mathbf{E}$ & Q & $\mathrm{P}$ & $\mathrm{Y}$ & $\mathrm{P}$ & $\underline{Q}$ & (Arentz-Hansen et al. 2002) \\
\hline DQ2.5-glia- $\gamma 4 \mathrm{a}$ & DQ2- $\gamma-\mathrm{IV}$ & $\mathrm{S}$ & $\mathrm{Q}$ & $\mathrm{P}$ & $\mathbf{E}$ & Q & $\mathbf{E}$ & $\mathrm{F}$ & $\mathrm{P}$ & $\bar{Q}$ & (Arentz-Hansen et al. 2002) \\
\hline DQ2.5-glia- $\gamma 4 \mathrm{~b}$ & DQ2- $\gamma$-VIIc & $\mathrm{P}$ & $\mathrm{Q}$ & $\mathrm{P}$ & $\mathbf{E}$ & $\mathrm{Q}$ & $\mathbf{E}$ & $\mathrm{F}$ & $\mathrm{P}$ & Q & (Qiao et al. 2005) \\
\hline DQ2.5-glia- $\gamma 4 c$ & DQ2- $\gamma$-VIIa & $\underline{Q}$ & $\mathrm{Q}$ & $\mathrm{P}$ & $\mathbf{E}$ & $\mathrm{Q}$ & $\mathrm{P}$ & $\mathrm{F}$ & $\mathrm{P}$ & Q & (Arentz-Hansen et al. 2002) \\
\hline DQ2.5-glia- $\gamma 4 \mathrm{~d}$ & DQ2- $\gamma-$ VIIb & $\mathrm{P}$ & Q & $\mathrm{P}$ & $\mathbf{E}$ & Q & $\mathrm{P}$ & $\mathrm{F}$ & $\mathrm{C}$ & $\underline{Q}$ & (Qiao, unpublished) \\
\hline DQ2.5-glia- $\gamma 5$ & DQ2- $\gamma-\mathrm{VI}$ & Q & Q & $\mathrm{P}$ & $\mathrm{F}$ & $\mathrm{P}$ & $\mathbf{E}$ & Q & $\mathrm{P}$ & Q & (Arentz-Hansen et al. 2002) \\
\hline DQ2.5-glia- $\omega 1$ & DQ2- $\omega-\mathrm{I}$ & $\mathrm{P}$ & $\mathrm{F}$ & $\mathrm{P}$ & Q & $\mathrm{P}$ & $\mathbf{E}$ & Q & $\mathrm{P}$ & $\mathrm{F}$ & (Tye-Din et al. 2010) \\
\hline DQ2.5-glia- $\omega 2$ & DQ2- $\omega-\mathrm{II}$ & $\mathrm{P}$ & Q & $\mathrm{P}$ & $\mathbf{E}$ & Q & $\mathrm{P}$ & $\mathrm{F}$ & $\mathrm{P}$ & $\mathrm{W}$ & (Tye-Din et al. 2010) \\
\hline DQ2.5-glut-L1 & glutenin-17 & $\mathrm{P}$ & $\mathrm{F}$ & $\mathrm{S}$ & $\mathbf{E}$ & Q & $\mathbf{E}$ & Q & $\mathrm{P}$ & $\mathrm{V}$ & (Vader et al. 2002b) \\
\hline DQ2.5-glut-L2 & glutenin-156 & $\mathrm{F}$ & $\mathrm{S}$ & $\underline{Q}$ & Q & Q & $\mathbf{E}$ & $\mathrm{S}$ & $\mathrm{P}$ & $\mathrm{F}$ & (Stepniak et al. 2005; Vader et al. 2002b) \\
\hline DQ2.5-hor-1 & Hor- $\alpha 9, \mathrm{H} \alpha 9$ & $\mathrm{P}$ & $\mathrm{F}$ & $\mathrm{P}$ & Q & $\mathrm{P}$ & $\mathbf{E}$ & Q & $\mathrm{P}$ & $\mathrm{F}$ & (Tye-Din et al. 2010; Vader et al. 2003a) \\
\hline DQ2.5-hor-2 & Hor- $\alpha 2, \mathrm{H} \alpha 2$ & $\mathrm{P}$ & Q & $\mathrm{P}$ & $\mathbf{E}$ & Q & $\mathrm{P}$ & $\mathrm{F}$ & $\mathrm{P}$ & Q & (Vader et al. 2003a) \\
\hline DQ2.5-hor-3 & hor-I-DQ2 & $\mathrm{P}$ & I & $\mathrm{P}$ & $\mathbf{E}$ & Q & $\mathrm{P}$ & Q & $\mathrm{P}$ & Y & (Tye-Din et al. 2010) \\
\hline DQ2.5-sec-1 & Sec- $\alpha 9, S \alpha 9$ & $\mathrm{P}$ & $\mathrm{F}$ & $\mathrm{P}$ & Q & $\mathrm{P}$ & $\mathbf{E}$ & Q & $\mathrm{P}$ & $\mathrm{F}$ & (Tye-Din et al. 2010; Vader et al. 2003a) \\
\hline DQ2.5-sec-2 & $\mathrm{Sec}-\alpha 2, \mathrm{~S} \alpha 2$ & $\mathrm{P}$ & Q & $\mathrm{P}$ & $\mathbf{E}$ & Q & $\mathrm{P}$ & $\mathrm{F}$ & $\mathrm{P}$ & Q & (Vader et al. 2003a) \\
\hline DQ2.5-ave-1a & $\mathrm{Av}-\alpha 9 \mathrm{~A}$ & $\mathrm{P}$ & $\mathrm{Y}$ & $\mathrm{P}$ & $\mathrm{E}$ & Q & $\mathbf{E}$ & $\mathrm{E}$ & $\mathrm{P}$ & $\mathrm{F}$ & (Arentz-Hansen et al. 2004; Vader et al. 2003a) \\
\hline DQ2.5-ave-1b & Av- $\alpha 9 \mathrm{~B}, 1490$ & $\mathrm{P}$ & $\mathrm{Y}$ & $\mathrm{P}$ & $\mathrm{E}$ & Q & $\mathbf{E}$ & Q & $\mathrm{P}$ & $\mathrm{F}$ & (Arentz-Hansen et al. 2004; Vader et al. 2003a) \\
\hline \multicolumn{12}{|c|}{ DQ2.2 restricted epitopes } \\
\hline DQ2.2-glut-L1 & glutenin-17 & $\mathrm{P}$ & $\mathrm{F}$ & $\mathrm{S}$ & $\mathbf{E}$ & Q & $\mathbf{E}$ & Q & $\mathrm{P}$ & $\mathrm{V}$ & (Bodd et al. 2012) \\
\hline \multicolumn{12}{|c|}{ DQ8 restricted epitopes } \\
\hline DQ8-glia- $\alpha 1$ & DQ8- $\alpha-\mathrm{I}$ & $\mathbf{E}$ & $\mathrm{G}$ & $\mathrm{S}$ & $\mathrm{F}$ & Q & $\mathrm{P}$ & $\mathrm{S}$ & Q & $\mathbf{E}$ & (van de Wal et al. 1998b) \\
\hline DQ8-glia- $\gamma 1 \mathrm{a}$ & DQ8- $\gamma-\mathrm{Ia}$ & $\mathbf{E}$ & Q & $\mathrm{P}$ & $\underline{Q}$ & $\mathrm{Q}$ & $\mathrm{P}$ & $\mathrm{F}$ & $\mathrm{P}$ & Q & (Tollefsen et al. 2006) \\
\hline DQ8-glia- $\gamma 1 b$ & DQ8- $\gamma-\mathrm{Ib}$ & $\mathbf{E}$ & $\mathrm{Q}$ & $\mathrm{P}$ & $\underline{Q}$ & $\mathrm{Q}$ & $\mathrm{P}$ & $\mathrm{Y}$ & $\mathrm{P}$ & $\mathbf{E}$ & (Tollefsen et al. 2006) \\
\hline DQ8-glut-H1 & HMW-glutenin & $\underline{Q}$ & G & $\mathrm{Y}$ & $\mathrm{Y}$ & $\mathrm{P}$ & $\mathrm{T}$ & $\mathrm{S}$ & $\mathrm{P}$ & $\underline{Q}$ & (van de Wal et al. 1999) \\
\hline \multicolumn{12}{|c|}{ DQ8.5 restricted epitopes } \\
\hline DQ8.5-glia- $\alpha 1$ & DQ8- $\alpha-I$ & $\mathbf{E}$ & G & $\mathrm{S}$ & $\mathrm{F}$ & Q & $\mathrm{P}$ & $\mathrm{S}$ & Q & $\mathbf{E}$ & (Kooy-Winkelaar et al. 2011) \\
\hline DQ8.5-glia- $\gamma 1$ & & $\mathrm{P}$ & $\mathrm{Q}$ & Q & $\mathrm{S}$ & $\mathrm{F}$ & $\mathrm{P}$ & $\mathbf{E}$ & Q & $\mathbf{E}$ & (Kooy-Winkelaar et al. 2011) \\
\hline DQ8.5-glut-H1 & HMW-glutenin & $\underline{Q}$ & G & $\mathrm{Y}$ & $\mathrm{Y}$ & $\mathrm{P}$ & $\mathrm{T}$ & $\mathrm{S}$ & $\mathrm{P}$ & $\underline{Q}$ & (Kooy-Winkelaar et al. 2011) \\
\hline
\end{tabular}

${ }^{a}$ In the epitope names, these short terms are used to denote the type of proteins that the epitopes derive from: 'glia- $\alpha$ ' denotes $\alpha$-gliadin, 'glia- $\gamma$ ' denotes $\gamma$-gliadin, 'glia- $\omega$ ' denotes $\omega$-gliadin, 'glut-L' denotes low molecular weight glutenin, 'glut-H' denotes high molecular weight glutenin, 'hor' denotes hordein, 'sec' denotes secalin and 'ave' denotes avenin

${ }^{\mathrm{b}}$ Glutamate residues (E) formed by TG2-medited deamidation which are important for recognition by T cells are shown in bold. Additional glutamine residues also targeted by TG2 are underlined

2. The HLA-restriction element involved must have been unequivocally defined.

3. The nine-amino acid core of the epitope must have been defined either by an analysis with truncated peptides and/or HLA-binding with lysine scan of the epitope or comparable approach.
Searching the literature using these criteria, we have compiled a list of epitopes (Table 2). This list includes sequences from $\alpha$-gliadin, $\gamma$-gliadin, $\omega$-gliadin, LMWand HMW-glutenins, hordeins, secalins and avenins. To note, most gluten-reactive $\mathrm{T}$ cells have minimal epitopes longer than those listed in Table 2. This is because MHC 
class II restricted T-cell receptors usually are sensitive to a few residues flanking the nine-amino acid core region of the epitopes.

In Table 2, some sequences that previously were defined as individual epitopes have been grouped together as members of the same family. This pertains to the DQ2.5-glia- $\alpha 1 \mathrm{a}$ and DQ2.5-glia- $\alpha 1 \mathrm{~b}$ as well as the DQ2.5-glia- $\gamma 4 \mathrm{a}, \mathrm{DQ} 2.5$ glia- $\gamma 4 \mathrm{~b}, \mathrm{DQ} 2.5$-glia- $\gamma 4 \mathrm{c}$ and DQ2.5-glia- $\gamma 4 \mathrm{~d}$ epitopes. The reason is that the sequences defining these epitopes are very similar, although there are occasionally $\mathrm{T}$-cell clones that can distinguish between members of the same epitope family (Arentz-Hansen et al. 2002; Qiao et al. 2005). Most T-cell clones appear to cross-react between peptide sequences of the same family.

The nine-amino acid core sequences of some of the DQ2.5 restricted epitopes are identical, but because these epitopes derive from different cereal species they are still listed as unique epitopes. This applies to the DQ2.5-glia- $\omega 1$, DQ2.5hor-1 and DQ2.5-sec-1 epitopes, as well as DQ2.5-hor-2 and DQ2.5-sec-2 epitopes. T-cell cross-reactivity between proteins of different species hence does often occur, but $T$ cells reactive with these epitopes can also be species-specific as the T-cell receptors may be sensitive to unique residues flanking the nine-amino acid core region of the epitopes. In addition, there are epitopes, like DQ2.5-hor-3 (Tye-Din et al. 2010), that have sequences which are hordein or secalin specific and which elicit species specific T-cell responses.

The majority of gluten-reactive $\mathrm{T}$ cells generated from DQ2.5 positive $C D$ patients can recognize their epitopes when confronted in vitro with antigen presenting cells expressing the closely related HLA-DQ2.2 molecule (DQA1*02:01, DQB1*02:01). Yet, DQ2.2 positive CD patients do not mount a T-cell response to the same gluten epitopes, but rather have responses to gluten peptides that bind stably to DQ2.2 (Bodd et al. 2012). When defining an epitope, it is thus important to assess and categorize the epitope only in the context of the HLA molecules that are expressed by the T-cell donor.

The selection of gluten T-cell epitopes is best understood in HLA-DQ2.5 positive CD patients, and is influenced by at least three factors: (a) resistance of the polypeptide sequence to proteolytic degradation, (b) specificity of TG2 and (c) HLA binding specificity. The proline-rich nature of gluten makes the gluten proteins resistant to proteolytic degradation in the gastrointestinal lumen, and long gluten peptide fragments ranging from 15 to 50 residues therefore survive in the small intestine (Shan et al. 2002). T-cell epitopes are often localized within such long fragments (Arentz-Hansen et al. 2002). The resulting proline and glutamine rich peptides are often good substrates for TG2 (Dørum et al. 2009, 2010; Fleckenstein et al. 2002; Vader et al. 2002a). Proline is influencing the specificity of TG2 as the enzyme typically recognizes glutamine residues in glutamine-X-proline sequences (Fleckenstein et al. 2002; Vader et al. 2002a). T-cell epitopes in their native form are usually very good substrates for TG2. TG2, being an important factor in the selection of T-cell epitopes, is demonstrated by the fact that TG2 is selectively targeting peptides which harbor T-cell epitopes from a digest of gluten with extreme complexity (Dørum et al. 2010). Finally, determinant selection by $\mathrm{MHC}$ is influencing repertoire of T-cell epitopes. In general, gluten peptides are poor binders to HLA class II molecules with the exception of HLA-DQ molecules associated with CD (Bergseng et al. 2008). Some gluten peptides also bind HLA-DR53 (Clot et al. 1999), although so far no T cells of celiac lesions recognizing these peptides have been described. The selective force of HLA is illustrated by the observation that the DQ2.5 and DQ8 epitopes generally come from non-overlapping sequences of gluten proteins (Tollefsen et al. 2006).

The glutamate introduced by TG2 is usually in position 4 (P4), P6 or P7 in HLA-DQ2.5 restricted epitopes and at position P1 and/or P9 in HLA-DQ8 restricted epitopes (Table 2). These glutamate residues serve as anchor residues important for binding of the peptides. Both HLA-DQ2.5 and DQ8 prefer negatively charged residues at these anchors sites. This positioning of deamidated glutamine residues is strongly related to the positioning of proline residues, which is particularly strict in the case of DQ2.5 epitopes, as DQ2.5 only accepts proline at certain position in the peptide binding groove (Kim et al. 2004). This results in a dominant presence of proline at P1, P6 and P8 and leads to the modification by TG2 of the glutamine residues at $\mathrm{P} 4$ and P6, respectively. Such positioning of proline residues is less strict in the case of the DQ8 epitopes. Although polyclonal T-cell responses to multiple T-cell epitopes are almost invariably found in $\mathrm{CD}$ patients, responses to the DQ2.5-glia$\alpha 1$ a, DQ2.5-glia- $\alpha 1$ b, DQ2.5-glia- $\alpha 2$ epitopes, DQ2.5-glia$\omega 1$, DQ2.5-glia- $\omega 2$, DQ2.5-hor-1 and DQ2-sec-1 are dominant in DQ2.5 positive patients (Arentz-Hansen et al. 2000; Camarca et al. 2009; Tollefsen et al. 2006; Tye-Din et al. 2010). In DQ8-positive patients, responses to the DQ8-glia$\alpha 1$ epitope are most frequently found (Tollefsen et al. 2006; van de Wal et al. 1998b).

The list of gluten epitopes recognized by $\mathrm{T}$ cells of $\mathrm{CD}$ patients presented in Table 2 will be extended as new epitopes become known in the future. A dedicated website (http://www.isscd.org/EpitopeNomenclature) will update this list as more epitopes are identified.

Open Access This article is distributed under the terms of the Creative Commons Attribution License which permits any use, distribution, and reproduction in any medium, provided the original author(s) and the source are credited. 


\section{References}

Anderson RP, Degano P, Godkin AJ, Jewell DP, Hill AV (2000) In vivo antigen challenge in celiac disease identifies a single transglutaminase-modified peptide as the dominant A-gliadin T-cell epitope. Nat Med 6:337-342

Anderson RP, van Heel DA, Tye-Din JA, Barnardo M, Salio M, Jewell DP, Hill AV (2005) T cells in peripheral blood after gluten challenge in coeliac disease. Gut 54:1217-1223

Arentz-Hansen H, Körner R, Molberg QH, Vader W, Kooy YM, Lundin KEA, Koning F, Roepstorff P, Sollid LM, McAdam SN (2000) The intestinal T cell response to $\alpha$-gliadin in adult celiac disease is focused on a single deamidated glutamine targeted by tissue transglutaminase. J Exp Med 191:603-612

Arentz-Hansen H, McAdam SN, Molberg FB, Lundin KE, Jorgensen TJ, Jung G, Roepstorff P, Sollid LM (2002) Celiac lesion T cells recognize epitopes that cluster in regions of gliadins rich in proline residues. Gastroenterology 123:803-809

Arentz-Hansen H, Fleckenstein B, Molberg SH, Koning F, Jung G, Roepstorff P, Lundin KE, Sollid LM (2004) The molecular basis for oat intolerance in patients with celiac disease. Plos Med 1:e1

Bergseng E, Sidney J, Sette A, Sollid LM (2008) Analysis of the binding of gluten T-cell epitopes to various human leukocyte antigen class II molecules. Hum Immunol 69:94-100

Bodd M, Kim CY, Lundin KE, Sollid LM (2012) Characterization of the T-cell reponse to gluten in patients with celiac disease expressing HLA-DQ2.2 but not any other HLA-DQ risk molecules. Gastroenterology, in press

Camarca A, Anderson RP, Mamone G, Fierro O, Facchiano A, Costantini S, Zanzi D, Sidney J, Auricchio S, Sette A, Troncone R, Gianfrani C (2009) Intestinal $T$ cell responses to gluten peptides are largely heterogeneous: implications for a peptide-based therapy in celiac disease. J Immunol 182:4158-4166

Clot F, Gianfrani C, Babron MC, Bouguerra F, Southwood S, Kagnoff MF, Troncone R, Percopo S, Eliaou JF, Clerget-Darpoux F, Sette A, Greco L (1999) HLA-DR53 molecules are associated with susceptibility to celiac disease and selectively bind gliadin-derived peptides. Immunogenetics 49:800-807

de Kauwe AL, Chen Z, Anderson RP, Keech CL, Price JD, Wijburg O, Jackson DC, Ladhams J, Allison J, McCluskey J (2009) Resistance to celiac disease in humanized HLA-DR3-DQ2-transgenic mice expressing specific anti-gliadin $\mathrm{CD}^{+} \mathrm{T}$ cells. $\mathrm{J}$ Immunol 182:7440-7450

Dørum S, Qiao SW, Sollid LM, Fleckenstein B (2009) A quantitative analysis of transglutaminase 2-mediated deamidation of gluten peptides: implications for the T-cell response in celiac disease. J Proteome Res 8:1748-1755

Dørum S, Arntzen MO, Qiao SW, Holm A, Koehler CJ, Thiede B, Sollid LM, Fleckenstein B (2010) The preferred substrates for transglutaminase 2 in a complex wheat gluten digest are peptide fragments harboring celiac disease T-cell epitopes. PLoS One 5: e14056

Du Pre MF, Kozijn AE, van Berkel LA, ter Borg MN, LindenberghKortleve D, Jensen LT, Kooy-Winkelaar Y, Koning F, Boon L, Nieuwenhuis EE, Sollid LM, Fugger L, Samsom JN (2011) Tolerance to ingested deamidated gliadin in mice is maintained by splenic, type 1 regulatory T cells. Gastroenterology 141:610-620, 620 e1-e2

Fallang LE, Bergseng E, Hotta K, Berg-Larsen A, Kim CY, Sollid LM (2009) Differences in the risk of celiac disease associated with HLA-DQ2.5 or HLA-DQ2.2 are related to sustained gluten antigen presentation. Nat Immunol 10:1096-10101

Fleckenstein B, Molberg QSW, Schmid DG, Von Der MF, Elgstoen K, Jung G, Sollid LM (2002) Gliadin T cell epitope selection by tissue transglutaminase in celiac disease. Role of enzyme specificity and $\mathrm{pH}$ influence on the transamidation versus deamidation process. J Biol Chem 277:34109-34116

Garsed K, Scott BB (2007) Can oats be taken in a gluten-free diet? A systematic review. Scand J Gastroenterol 42:171-178

Green PH, Cellier C (2007) Celiac disease. N Engl J Med 357:17311743

Henderson KN, Tye-Din JA, Reid HH, Chen Z, Borg NA, Beissbarth T, Tatham A, Mannering SI, Purcell AW, Dudek NL, van Heel DA, McCluskey J, Rossjohn J, Anderson RP (2007) A structural and immunological basis for the role of human leukocyte antigen DQ8 in celiac disease. Immunity 27:23-34

Karell K, Louka AS, Moodie SJ, Ascher H, Clot F, Greco L, Ciclitira PJ, Sollid LM, Partanen J (2003) HLA types in celiac disease patients not carrying the DQA1*05-DQB1*02 (DQ2) heterodimer: results from the European Genetics Cluster on Celiac Disease. Hum Immunol 64:469-477

Kim CY, Quarsten H, Bergseng E, Khosla C, Sollid LM (2004) Structural basis for HLA-DQ2-mediated presentation of gluten epitopes in celiac disease. Proc Natl Acad Sci U S A 101:41754179

Kooy-Winkelaar Y, van Lummel M, Moustakas AK, Schweizer J, Mearin ML, Mulder CJ, Roep BO, Drijfhout JW, Papadopoulos G, van Bergen J, Koning F (2011) Gluten-specific T cells crossreact between HLA-DQ8 and the HLA-DQ2 $\alpha / \mathrm{DQ} \beta$ transdimer. J Immunol 187:5123-5129

Lundin KEA, Scott H, Hansen T, Paulsen G, Halstensen TS, Fausa O, Thorsby E, Sollid LM (1993) Gliadin-specific, HLA-DQ $\left(\alpha 1 * 0501, \beta 1^{*} 0201\right)$ restricted $\mathrm{T}$ cells isolated from the small intestinal mucosa of celiac disease patients. J Exp Med 178:187196

Lundin KEA, Scott H, Fausa O, Thorsby E, Sollid LM (1994) T cells from the small intestinal mucosa of a DR4, DQ7/DR4, DQ8 celiac disease patient preferentially recognize gliadin when presented by DQ8. Hum Immunol 41:285-291

Lundin KEA, Nilsen EM, Scott HG, Løberg EM, Gjøen A, Bratlie J, Skar V, Mendez E, Løvik A, Kett K (2003) Oats induced villous atrophy in coeliac disease. Gut 52:1149-1152

Molberg O, Kett K, Scott H, Thorsby E, Sollid LM, Lundin KEA (1997) Gliadin specific, HLA DQ2-restricted T cells are commonly found in small intestinal biopsies from coeliac disease patients, but not from controls. Scand J Immunol 46:103-109

Molberg O, McAdam SN, Körner R, Quarsten H, Kristiansen C, Madsen L, Fugger L, Scott H, Roepstorff P, Lundin KEA, Sjöström H, Sollid LM (1998) Tissue transglutaminase selectively modifies gliadin peptides that are recognized by gut-derived T cells. Nat Med 4:713-717

Moustakas AK, van de Wal Y, Routsias J, Kooy YM, Van Veelen P, Drijfhout JW, Koning F, Papadopoulos GK (2000) Structure of celiac disease-associated HLA-DQ8 and non-associated HLADQ9 alleles in complex with two disease-specific epitopes. Int Immunol 12:1157-1166

Qiao SW, Bergseng E, Molberg O, Jung G, Fleckenstein B, Sollid LM (2005) Refining the rules of gliadin T cell epitope binding to the disease-associated DQ2 molecule in celiac disease: importance of proline spacing and glutamine deamidation. J Immunol 175:254 261

Quarsten H, Molberg FL, McAdam SN, Sollid LM (1999) HLA binding and $\mathrm{T}$ cell recognition of a tissue transglutaminasemodified gliadin epitope. Eur J Immunol 29:2506-2514

Ráki M, Fallang LE, Brottveit M, Bergseng E, Quarsten H, Lundin KE, Sollid LM (2007) Tetramer visualization of gut-homing glutenspecific T cells in the peripheral blood of celiac disease patients. Proc Natl Acad Sci U S A 104:2831-2836

Shan L, Molberg PI, Hausch F, Filiz F, Gray GM, Sollid LM, Khosla C (2002) Structural basis for gluten intolerance in celiac sprue. Science 297:2275-2279 
Shewry PR, Tatham AS, Kasarda DD (1992) Cereal proteins and coeliac disease. In: Marsh MN (ed) coeliac disease. Blackwell Scientific Publications, Oxford

Sjöström H, Lundin KEA, Molberg KR, McAdam SN, Anthonsen D, Quarsten H, Noren O, Roepstorff P, Thorsby E, Sollid LM (1998) Identification of a gliadin T-cell epitope in coeliac disease: general importance of gliadin deamidation for intestinal T-cell recognition. Scand J Immunol 48:111-115

Sollid LM (2002) Coeliac disease: dissecting a complex inflammatory disorder. Nat Rev Immunol 2:647-655

Sollid LM, Markussen G, Ek J, Gjerde H, Vartdal F, Thorsby E (1989) Evidence for a primary association of celiac disease to a particular HLA-DQ $\alpha / \beta$ heterodimer. J Exp Med 169:345350

Stepniak D, Vader LW, Kooy Y, van Veelen PA, Moustakas A, Papandreou NA, Eliopoulos E, Drijfhout JW, Papadopoulos GK, Koning F (2005) T-cell recognition of HLA-DQ2-bound gluten peptides can be influenced by an $\mathrm{N}$-terminal proline at $\mathrm{p}-1$. Immunogenetics 57:8-15

Tollefsen S, Arentz-Hansen H, Fleckenstein B, Molberg RM, Kwok WW, Jung G, Lundin KE, Sollid LM (2006) HLA-DQ2 and -DQ8 signatures of gluten $\mathrm{T}$ cell epitopes in celiac disease. J Clin Invest 116:2226-2236

Trynka G, Hunt KA, Bockett NA, Romanos J, Mistry V, Szperl A, Bakker SF, Bardella MT, Bhaw-Rosun L, Castillejo G, de la Concha EG, de Almeida RC, Dias KR, van Diemen CC, Dubois PC, Duerr RH, Edkins S, Franke L, Fransen K, Gutierrez J, Heap GA, Hrdlickova B, Hunt S, Izurieta LP, Izzo V, Joosten LA, Langford C, Mazzilli MC, Mein CA, Midah V, Mitrovic M, Mora B, Morelli M, Nutland S, Nunez C, Onengut-Gumuscu S, Pearce K, Platteel M, Polanco I, Potter S, Ribes-Koninckx C, RicanoPonce I, Rich SS, Rybak A, Santiago JL, Senapati S, Sood A, Szajewska H, Troncone R, Varade J, Wallace C, Wolters VM, Zhernakova A, Thelma BK, Cukrowska B, Urcelay E, Bilbao JR, Mearin ML, Barisani D, Barrett JC, Plagnol V, Deloukas P, Wijmenga C, van Heel DA (2011) Dense genotyping identifies and localizes multiple common and rare variant association signals in celiac disease. Nat Genet 43:1193-1201
Tye-Din JA, Stewart JA, Dromey JA, Beissbarth T, van Heel DA, Tatham A, Henderson K, Mannering SI, Gianfrani C, Jewell DP, Hill AV, McCluskey J, Rossjohn J, Anderson RP (2010) Comprehensive, quantitative mapping of $\mathrm{T}$ cell epitopes in gluten in celiac disease. Sci Transl Med 2:41ra51

Vader LW, de Ru A, van Der WY, Kooy YM, Benckhuijsen W, Mearin ML, Drijfhout JW, van Veelen P, Koning F (2002a) Specificity of tissue transglutaminase explains cereal toxicity in celiac disease. $\mathrm{J}$ Exp Med 195:643-649

Vader W, Kooy Y, van Veelen P, de Ru A, Harris D, Benckhuijsen W, Pena S, Mearin L, Drijfhout JW, Koning F (2002b) The gluten response in children with celiac disease is directed toward multiple gliadin and glutenin peptides. Gastroenterology 122:17291737

Vader LW, Stepniak DT, Bunnik EM, Kooy YM, de Haan W, Drijfhout JW, van Veelen PA, Koning F (2003a) Characterization of cereal toxicity for celiac disease patients based on protein homology in grains. Gastroenterology 125:1105-1113

Vader W, Stepniak D, Kooy Y, Mearin L, Thompson A, van Rood JJ, Spaenij L, Koning F (2003b) The HLA-DQ2 gene dose effect in celiac disease is directly related to the magnitude and breadth of gluten-specific T cell responses. Proc Natl Acad Sci U S A 100:12390-12395

van de Wal Y, Kooy Y, van Veelen P, Pena S, Mearin L, Papadopoulos G, Koning F (1998a) Selective deamidation by tissue transglutaminase strongly enhances gliadin-specific T cell reactivity. J Immunol 161:1585-1588

van de Wal Y, Kooy YM, van Veelen PA, Pena SA, Mearin LM, Molberg LKEA, Sollid LM, Mutis T, Benckhuijsen WE, Drijfhout JW, Koning F (1998b) Small intestinal T cells of celiac disease patients recognize a natural pepsin fragment of gliadin. Proc Natl Acad Sci U S A 95:10050-10054

van de Wal Y, Kooy YM, van Veelen P, Vader W, August SA, Drijfhout JW, Pena SA, Koning F (1999) Glutenin is involved in the glutendriven mucosal T cell response. Eur J Immunol 29:3133-3139

Xia J, Sollid LM, Khosla C (2005) Equilibrium and kinetic analysis of the unusual binding behavior of a highly immunogenic gluten peptide to HLA-DQ2. Biochemistry 44:4442-4449 